\title{
FAKTOR DETERMINAN KONSISTENSI PEMAKAIAN KONDOM PADA PEKERJA SEKS PEREMPUAN
}

\section{DETERMINANT FACTOR TOWARDS CONSISTENCY OF CONDOM USE AMONG WOMEN SEXUAL WORKERS}

\author{
Dwi Murtono \\ Rumah Sakit Daerah Kayen Kabupaten Pati \\ Jl. Rumah Sakit No.1 Kayen. Pati 59171. Jawa Tengah \\ Email: dwi_murt@yahoo.com
}

\begin{abstract}
Awareness level of condom use consistently among high-risk groups is still low. HIV/AIDS incidents can be triggered by inconsistency of condom use. The purpose of this research was to determine the factors associated with the consistency of condom usage in female sex workers. The research used a quantitative descriptive approach with a cross sectional design. The research period was from June to September 2018 with the location of research in the prostitution areas in Margorejo Subdistrict, Pati. Sample selection used incidental sampling with 70 respondents. Data analysis used Chi square (X2) with Confidence Interval (CI) value of $95 \%(\alpha=0.05)$ by using $2 \times 2$ table. The results of the research: factors that are related to the consistency of condom use in female sex workers are income level and marital status. Low income sex workers will try to find clients as many as possible without using a condom. Meanwhile, the married clients or those who have wife tended to use condom when having sex with female sex workers due to protecting their spouses.
\end{abstract}

Keywords: condom, consistency, female sex worker

\begin{abstract}
ABSTRAK
Kesadaran untuk menggunakan kondom secara konsisten pada kelompok seks berisiko masih rendah. Kejadian HIVIAIDS salah satunya dipicu oleh kelompok yang mempunyai perilaku penggunaan kondom yang tidak konsisten. Tujuan penelitian ini adalah untuk mengetahui faktor yang berhubungan dengan konsistensi pemakaian kondom pada pekerja seks perempuan (PSP). Penelitian menggunakan pendekatan deskriptif kuantitatif dengan rancangan desain potong lintang. Waktu penelitian bulan Juni sampai dengan September 2018 dengan lokasi penelitian di Lokalisasi Kecamatan Margorejo. Pemilihan sampel dengan insidental sampling dengan jumlah 70 responden. Analisis data menggunakan Chi square $\left(X^{2}\right)$ dengan nilai Confidence Interval (CI) sebesar 95\% $(\alpha=0,05)$ dengan menggunakan tabel $2 \times 2$. Hasil penelitian yaitu faktor yang berhu- bungan dengan konsistensi pemakaian kondom pada pekerja seks perempuan adalah tingkat penghasilan dan status pernikahan. Pekerja seks dengan penghasilan rendah akan berusaha mencari pelanggan sebanyak-banyaknya tanpa memakai kondom. Laki-laki yang telah menikah dan memiliki pasangan resmi (istri) cenderung untuk menggunakan kondom saat melakukan hubungan seks dengan pekerja seks perempuan untuk mencegah adanya dampak negatif terhadap pasangan resminya.
\end{abstract}

Kata kunci : kondom, konsistensi, pekerja seks perempuan

\section{PENDAHULUAN}

Epidemi Human Immunodeficiency
Virus (HIV) di Indonesia biasanya
dihubungkan dengan pengguna jarum suntik
(Penasun) dan Pekerja Seks Perempuan (PSP).
Namun demikian, saat ini situasi epidemi HIV

dan Acquired Immune Deficiency Syndrome (AIDS) telah berubah. Pada tahun mendatang, kelompok terbesar pengidap infeksi HIV diproyeksikan akan terjadi di antara laki-laki yang berhubungan seks dengan laki-laki (LSL) dan perempuan pada populasi umum (perempuan risiko rendah), yang terdiri dari 
perempuan terinfeksi melalui hubungan seksual dengan pasangan yang telah terinfeksi, perempuan yang melakukan perilaku berisiko pada tahun-tahun sebelumnya, dan mereka yang sebenarnya telah terinfeksi HIV dan baru dapat terdeteksi di kemudian hari. Infeksi HIV pada laki-laki cukup banyak terjadi pada kelompok laki-laki yang merupakan pelanggan pekerja seks dan laki-laki populasi umum, yang terdiri dari laki-laki yang terinfeksi melalui hubungan seksual dengan istri-istri mereka, ditambah dengan laki-laki yang berhubungan seks dengan PSP pada tahun sebelumnya (Kemenkes RI, 2014).

Berdasarkan laporan Dinas Kesehatan Kabupaten Pati (2015), terdapat 695 Orang Dengan HIV/AIDS (ODHA) hingga bulan Maret 2015. Akhir Maret 2015, Kabupaten Pati menempati peringkat keempat di Provinsi Jawa Tengah dalam penemuan kasus baru HIV/AIDS. Berdasarkan laporan triwulan I Kemenkes RI (2017), jumlah infeksi HIV yang dilaporkan untuk Kabupaten Pati sebanyak 10.376 orang dan jumlah penderita AIDS dilaporkan sebanyak 673 orang. Hal ini mengindikasikan bahwa jumlah pengidap HIV/AIDS bertambah dalam kurun waktu dua tahun terakhir.

Keberadaan tempat hiburan karaoke/cafe maupun lokalisasi di Kabupaten Pati diperkirakan menjadi salah satu penyebab semakin cepatnya penyebaran HIV/AIDS dan tingginya potensi Infeksi Menular Seksual (IMS) di Kabupaten Pati (KPAK Pati, 2014). LSM Fatayat NU SSR II (2018) mendata sampai bulan Mei 2018, terdapat sekitar 30 tempat karaoke/cafe di Kabupaten Pati dengan jumlah pekerja wanita yang bervariasi antara 12 sampai 100 orang. Adapun jumlah lokalisasi di Kabupaten Pati berjumlah 6 dengan jumlah PSP sebanyak 275 orang. Salah satu wilayah di Kabupaten Pati yang memiliki tempat-tempat hiburan berupa tempat karaoke, cafe dan lokalisasi adalah Kecamatan Margorejo. Meskipun diperkirakan terdapat kantong-kantong keberadaan PSP, belum terdapat data pasti mengenai jumlah PSP di Kecamatan Margorejo. Hal tersebut menyebabkan meningkatnya risiko penyebaran HIV/AIDS dan IMS di Kabupaten Pati.

Centers for Disease Control and Prevention (2010) mendefinisikan Penyakit
Menular Seksual (PMS) atau sekarang disebut Infeksi Menular Seksual (IMS) sebagai berbagai macam sindrom klinis yang disebabkan oleh kuman yang ditularkan melalui aktivitas seksual. Menurut WHO dalam Kemenkes RI (2011), IMS adalah sekelompok penyakit infeksi yang penyebarannya terjadi melalui kontak seksual manusia dengan manusia. Hasil penelitian Ilmawan, dkk. dalam Susanti \& Nirmasari (2015) menyebutkan bahwa hingga tahun 2015 diperkirakan terdapat 340 juta kasus penyakit menular seksual yang dapat disembuhkan ditemukan setiap tahunnya di seluruh dunia pada pria dan wanita berusia 15 49 tahun. Angka kejadian tertinggi terjadi pada kelompok usia 20-24 tahun, diikuti dengan kelompok usia 15-19 tahun.

Tingginya prevalensi maupun insiden IMS tersebut berkaitan dengan praktik perilaku pencegahan IMS yang masih sangat rendah, seperti rendahnya angka penggunaan kondom pada seks berisiko, dan tingginya angka berganti pasangan. Pekerja Seks Perempuan (PSP) menjadi salah satu penyebab risiko tinggi terjadinya penyakit infeksi menular seksual (Sembiring \& Sembiring, 2013). Murtono, dkk. (2018) dalam penelitiannya tentang faktor host yang berpengaruh terhadap kejadian HIV/AIDS pada populasi kunci di Kabupaten Pati menyimpulkan bahwa sebagian besar $(67,92 \%)$ responden mempunyai perilaku penggunaan kondom yang tidak konsisten. Sementara itu, kelompok kasus mempunyai perilaku penggunaan kondom yang tidak konsisten $(94,34 \%)$, sama seperti pada kelompok kontrol.

Penggunaan kondom secara tepat dapat meminimalisir terjadinya penularan HIV meskipun tidak dapat mencegah penularan virus tersebut. Efektifitas kondom sebagai pelindung menurut prosedur tetap yang berlaku dalam satuan produk (batch) kondom yang dijual di pasar, apabila dalam 1000 buah kondom tidak ada yang dapat dilewati partikel sebesar 5 mikron. Kajian di lapangan, hanya satu dari 10.000 kondom yang mampu melewatkan virus HIV. Budiono (2012) menyebutkan, faktor yang menyebabkan kondom tidak efektif, diantaranya kualitas kondom, masa kadaluarsa, pemasangan dan pelepasan kondom yang salah, cara 
membuang kondom bekas yang salah, dan aktifitas seks yang berlebihan. Budiono (2012) menambahkan faktor yang menyebabkan kondom tidak efektif karena robek dan meleset (keluar dari zakar tanpa disadari). Sementara itu, penambahan pelumas dapat menurunkan angka kondom robek namun bisa meningkatkan angka kondom meleset.

Faktor umur, pendidikan, penghasilan, dan status pernikahan patut dikaji untuk melihat keterkaitannya dengan penularan IMS maupun HIV/AIDS. Penelitian Fauza, dkk. (2014) menyebutkan bahwa tidak terdapat hubungan yang bermakna antara pendidikan PSP dengan tindakan penggunaan kondom untuk pencegahan IMS di Lokalisasi Sukosari Bawen. Selain itu, tidak terdapat hubungan yang bermakna antara sikap PSP dengan tindakan penggunaan kondom untuk pencegahan PMS di Lokalisasi tersebut.

Ismiati \& Susmini (2018) menyebutkan bahwa terdapat hubungan antara penggunaan kondom dengan kejadian IMS dan hubungan antara status perkawinan dengan kejadian IMS wanita usia produktif di wilayah Puskesmas Betungan Kota Bengkulu. Penelitian Sumiyati \& Hadi (2013) menunjukkan bahwa hanya faktor dukungan istri yang berhubungan dengan penggunaan kondom. Sementara, faktor pengetahuan suami, pendidikan suami, pekerjaan suami, umur suami, umur istri, jumlah anak, keberadaan sumber informasi tentang $\mathrm{KB}$ pria, kontak petugas kesehatan tidak berhubungan dengan penggunaan kondom. Berdasarkan latar belakang tersebut, maka tujuan penelitian adalah mengetahui faktor determinan (penentu) konsistensi pemakaian kondom pada PSP di Lokalisasi Kecamatan Margorejo Kabupaten Pati.

\section{TINJAUAN PUSTAKA}

\section{HIV/AIDS}

HIV atau Human Immunodeficiency Virus adalah sejenis virus yang menyerang/ menginfeksi sel darah putih sehingga menurunkan kekebalan tubuh manusia (Kemenkes RI, 2014). UNICEF (2004) mendefinisikan HIV sebagai virus yang menyerang dan merusak sistem kekebalan tubuh sehingga tidak bisa bertahan terhadap penyakit-penyakit yang menyerang tubuh.
Acquired Immune Deficiency Syndrome atau AIDS adalah sekumpulan gejala penyakit yang timbul karena turunnya kekebalan tubuh akibat infeksi oleh HIV. Sebagai akibatnya, orang yang terinfeksi HIV sangat mudah terkena berbagai penyakit infeksi (infeksi oportunistik) yang sering berakibat fatal (Kemenkes RI, 2014). Menurut Lokollo (2009), AIDS merupakan kumpulan gejala menghilangnya atau berkurangnya kemampuan seseorang mengatasi infeksi, sehingga orang tersebut akan mudah mengalami infeksi bakteri, virus, atau jamur yang pada orang normal tidak menimbulkan penyakit (infeksi oportunistik).

Gejala AIDS timbul setelah 5-10 tahun setelah terinfeksi HIV. Beberapa orang tidak mengalami gejala saat terinfeksi pertama kali. Sementara yang lainnya mengalami gejalagejala seperti flu, termasuk demam, kehilangan nafsu makan, berat badan turun, lemah, dan pembengkakan saluran getah bening. Gejala-gejala tersebut biasanya menghilang dalam seminggu sampai sebulan namun virus tetap ada dalam kondisi tidak aktif (dormant) selama beberapa tahun. Virus tersebut secara terus menerus melemahkan sistem kekebalan, menyebabkan orang yang terinfeksi semakin tidak dapat bertahan terhadap infeksi-infeksi oportunistik.

Pengobatan untuk infeksi virus HIV/ AIDS belum ada. Pengidap HIV memerlukan pengobatan dengan Antiretroviral (ARV) untuk menurunkan jumlah virus HIV di dalam tubuh agar tidak masuk ke dalam stadium AIDS. Pengidap AIDS memerlukan pengobatan ARV untuk mencegah terjadinya infeksi oportunistik dengan berbagai komplikasinya (Kementerian Kesehatan RI, 2014). Lokollo (2009) menambahkan bahwa obat-obat antiretroviral digunakan untuk menjaga kesehatan dan memperpanjang hidup orang yang terinfeksi. Selain itu, obat-obat lain digunakan untuk melawan infeksi oportunistik yang juga diderita. Konsekuensi yang mungkin terjadi pada orang yang terinfeksi HIV yaitu orang tersebut meninggal karena komplikasi yang berhubungan dengan AIDS. Pengidap AIDS dapat meninggal bukan semata-mata oleh virus HIV, tetapi oleh penyakit lain yang sebenarnya bisa ditolak ketika daya tahan tubuhnya tidak rusak. 


\section{Infeksi Menular Seksual (IMS)}

Peraturan Menteri Kesehatan Republik Indonesia Nomor 21 Tahun 2013 menyebutkan bahwa Infeksi Menular Seksual (IMS) adalah infeksi yang ditularkan melalui hubungan seksual secara vaginal, anal/lewat anus dan oral/dengan mulut. Penyebab IMS adalah bakteri, virus, parasit, atau jamur yang ditularkan dari satu orang ke orang lain melalui kontak atau hubungan seksual (Marmi, 2013). Infeksi menular seksual merupakan salah satu penyebab masalah kesehatan, sosial dan ekonomi di banyak negara serta merupakan salah satu pintu masuk penularan virus HIV. Kasus IMS telah menimbulkan pengaruh besar dalam pengendalian HIV/AIDS. Pada saat yang sama, timbul peningkatan kejadian resistensi kuman penyebab IMS terhadap beberapa antimikroba, yang akan menambah masalah dalam pengobatan IMS (Kementerian Kesehatan, 2011). Mencegah dan mengobati IMS dapat mengurangi risiko penularan HIV melalui hubungan seks, terutama pada populasi yang paling memungkinkan untuk memiliki banyak pasangan seksual, misalnya penjaja seks dan pelanggannya. Keberadaan IMS dengan bentuk inflamasi atau ulserasi akan meningkatkan risiko masuknya infeksi HIV saat melakukan hubungan seks tanpa pelindung antara seorang yang telah terinfeksi IMS dengan pasangannya yang belum tertular. Ulkus genitalis (luka pada kelamin) diperkirakan meningkatkan risiko tertular HIV 50-300 kali setiap melakukan hubungan seksual tanpa kondom (Centers of Desease Control and Preven, 2014).

\section{Pekerja Seks Perempuan (PSP)}

Kartono dalam Aini (2014) menuliskan bahwa pekerja seks merupakan perilaku penjualan diri baik perempuan maupun lakilaki dengan jalan memperjualbelikan badan, kehormatan dan kepribadian kepada banyak orang untuk memuaskan nafsu-nafsu seks dengan imbalan pembayaran. Ninik, dkk. (2012) secara lebih spesifik menyebutkan Pekerja Seks Perempuan (PSP) adalah wanitawanita yang bekerja menjual atau menyewakan tubuhnya untuk kenikmatan orang lain dengan mengharapkan suatu imbalan atau upah. Profesi ini dilakukan dengan cara menjual jasa untuk memuaskan kebutuhan seksual pelanggan. Pada umumnya, pelayanan ini dalam bentuk menyewakan badannya. Perilaku tidak konsisten dalam menggunakan kondom saat berhubungan seks dapat meningkatkan kemungkinan penularan HIV yang lebih luas di masyarakat.

Seseorang yang terjerumus ke dalam prostitusi antara lain disebabkan oleh karena konflik mental, situasi hidup yang tidak menguntungkan pada masa anak-anak dan remaja, pola perilaku yang kurang dewasa, dan intelegensi yang rendah (Sofia, 2010). Selanjutnya, Sofia (2010) memaparkan beberapa faktor penyebab timbulnya pelacuran antara lain:

1. Tidak adanya undang-undang yang melarang pelacuran, juga tidak adanya larangan-larangan terhadap orang-orang yang melakukan pelacuran.

2. Adanya keinginan dan dorongan manusia untuk menyalurkan kebutuhan seks, khususnya di luar ikatan perkawinan.

3. Memberontak terhadap otoritas orang tua.

4. Adanya kebutuhan seks yang normal akan tetapi tidak dapat dipuaskan oleh pihak suami, misalnya karena suami impoten.

5. Ajakan teman-teman sekampung atau sekota yang sudah terjun lebih dahulu dalam dunia pelacuran.

Lokollo (2009) menyebutkan bahwa berdasarkan cara bekerjanya, pekerja seks perempuan dapat dibedakan menjadi 2 (dua) macam, yaitu :

1. PSP Langsung (Direct Sex Worker) yaitu wanita yang secara terbuka menjajakan seks baik di jalanan maupun di lokalisasi atau ekslokalisasi.

2. PSP Tidak Langsung (Indirect Sex Worker) yaitu wanita yang beroperasi secara terselubung sebagai penjaja seks komersial. PSP tidak langsung biasanya bekerja pada bidang pekerjaan tertentu atau mempunyai pekerjaan utama lain dan secara tidak langsung menjajakan seks di tempat hiburan seperti pemijat, pramuria bar, atau sebagai sales. PSP tidak langsung juga dapat diartikan sebagai wanita yang melayani seks pelanggannya untuk memperoleh tambahan pendapatan, seperti wanita yang bekerja di panti pijat/salon/ spa, bar/karaoke/diskotek/kafe restoran, dan hotel/motel/cottage. 


\section{Kondom}

Kondom adalah suatu selubung/sarung karet yang terbuat dari berbagai bahan diantaranya lateks (karet), plastik, atau bahan alami (produk hewani) yang dapat dipasang pada penis saat berhubungan seksual (Kurnia, 2013). Kata kondom berasal dari kata Latin condus yang berarti baki atau nampan penampung. Kondom semacam kantung yang disarungkan ke penis yang ereksi sebelum melakukan hubungan seksual (Ramadhani dalam Rustam, 2016).

Penggunaan kondom pada hubungan seksual berisiko merupakan salah satu strategi yang dapat dilakukan untuk mencegah penularan IMS dan HIV pada kelompok berisiko termasuk kepada PSP dan pelanggannya (Wirastri, dkk., 2017). Salah satu kebijakan penanggulangan HIV/AIDS adalah upaya pencegahan yang efektif termasuk penggunaan kondom $100 \%$ diantara PSP dengan pelanggannya, pasangan ODHA serta pemanfaatan fungsi ganda (dual protection) kondom dalam keluarga (Marlina, dkk., 2010).

\section{Faktor-faktor yang Mempengaruhi Peggunaan Kondom}

\section{Umur}

Umur adalah adalah satuan waktu yang mengukur waktu keberadaan suatu benda atau makhluk hidup, baik yang hidup maupun yang mati, misalnya usia manusia dikatakan lima belas tahun diukur sejak dia lahir hingga usia tersebut dihitung. Usia berkaitan dengan perubahan biologis manusia. Usia memberikan kemungkinan pengaruh terhadap perubahan perilaku seksual. Usia produktif 2445 tahun merupakan kategori usia seks aktif dengan dorongan seks yang tinggi pula. Apabila tidak disalurkan dengan benar, dorongan seksual yang tinggi tersebut dapat memicu seseorang untuk melakukan perilaku berisiko (Iskandar, 2014). Berdasarkan variabel umur, responden penelitian dibedakan menjadi dua kelompok, yaitu (a) 24-45 tahun dan (b) $<23$ tahun dan $>45$ tahun. Pengkategorian tersebut didasarkan pada alasan kelompok usia 24-45 tahun cenderung melakukan perilaku seksual lebih aktif dibandingkan dengan kelompok usia $<23$ tahun dan $>45$ tahun.

\section{Penghasilan}

Perekonomian yang kurang mencukupi di perdesaan membuat banyak orang mencari pekerjaan di perkotaan. Kemiskinan seringkali menyebabkan seseorang melakukan pekerjaan berisiko misalnya sebagai pekerja seks. Ketergantungan ekonomi menyebabkan seseorang sulit untuk mengontrol agar dirinya tidak terinfeksi karena tidak bisa menolak atau meminta pasangan atau pelanggan untuk menggunakan kondom ketika berhubungan seks (Musyarofah, 2014). Populasi kunci yang berpenghasilan rendah cenderung akan kesulitan mengakses layanan kesehatan apabila mengalami sakit, terutama sakit IMS. Biaya perjalanan menuju ke fasilitas kesehatan, biaya pemeriksaan, biaya obat cukup besar, terlebih lagi apabila sampai rawat inap. Pembagian responden berdasarkan penghasilan didasarkan pada penelitian yang oleh Murtono (2016) pada kelompok kunci HIV/AIDS yang membagi responden dalam dalam dua kelompok, yaitu kelompok dengan penghasilan $\leq \mathrm{Rp} 1.200 .000,00$ dan kelompok dengan penghasilan $>$ Rp1.200.000,00.

\section{Tingkat Pendidikan}

Tingkat pendidikan merupakan salah satu faktor predisposisi dalam membentuk perilaku kesehatan. Tingkat pendidikan seseorang berpengaruh terhadap wawasan dan cara pandangnya dalam menghadapi suatu masalah. Seseorang dengan pendidikan tinggi cenderung mengedepankan rasio pada saat menghadapi gagasan baru. Hal tersebut selaras dengan penelitian oleh Budiono (2012) bahwa pengetahuan tentang HIV dan IMS meningkatkan perilaku seksual secara aman di kalangan Pekerja Seks Perempuan (PSP). Berdasarkan variabel tingkat pendidikan, responden penelitian dikelompokkan menjadi dua, yaitu kelompok dengan tingkat pendidikan $\leq$ SMP dan kelompok dengan tingkat pendidikan $>$ SMP. Tingkat pendidikan SMP menjadi batasan karena merupakan batas pendidikan wajib dasar di Indonesia.

\section{Status Pernikahan}

Status pernikahan berhubungan dengan perilaku seksual sebagai faktor risiko kejadian HIV/AIDS. Tujuan utama manusia menikah adalah untuk mendapatkan keturunan, menyalurkan hasrat seksual secara legal 
agama dan negara. Bagi laki-laki dan perempuan yang belum menikah, tetapi memiliki hasrat seksual yang tinggi, akan cenderung melakukan perilaku seksual berisiko yaitu seks pranikah, ganti-ganti pasangan dan pergi ke tempat lokalisasi (Aeni, 2015). Oleh karena itu, responden penelitian diklasifikasikan dalam dua kelompok, yaitu responden dengan status belum menikah/janda dan responden dengan status menikah.

\section{METODE PENELITIAN}

Penelitian ini menggunakan pendekatan deskriptif kuantitatif dengan rancangan desain potong lintang. Penelitian dilaksanakan mulai bulan Juni sampai September 2018 dengan lokasi penelitian di Lokalisasi Kecamatan Margorejo. Sumber data berasal dari data primer dan data sekunder. Data primer diperoleh dari wawancara langsung pada Pekerja Seks Perempuan (PSP) di Lokalisasi Kecamatan Margorejo dan data sekunder dari DKK Pati dan Klinik VCT RSUD Kayen dengan menggunakan kuesioner.

Pemilihan sampel menggunakan metode Insidental Sampling. Sampel Penelitian adalah PSP di lokalisasi Kecamatan Margorejo. Jumlah sampel sebanyak 70 orang, yang terbagi di dua lokasi, yaitu Wagenan dan Lorog Indah. Jumlah sampel penelitian di Lokalisasi Wagenan adalah 28 orang (40\%), se- dangkan sampel di lokalisasi Lorog Indah berjumlah 42 orang $(60 \%)$. Variabel terikat yang diuji adalah konsistensi pemakaian kondom dan variabel bebas adalah umur, penghasilan, tingkat pendidikan, dan status pernikahan.

Analisis yang digunakan pada penelitian ini adalah analisis univariat dan analisis bivariat. Analisis univariat dilakukan untuk mendeskripsikan variabel terikat dan variabel bebas menggunakan tabel distribusi frekuensi. Analisis bivariat digunakan untuk melihat hubungan masing-masing variabel bebas dengan variabel konsistensi menggunakan kondom. Pengujian bivariat menggunakan uji Chi Square $\left(\mathrm{X}^{2}\right)$ dengan nilai Confidence Interval (CI) sebesar 95\% $(\alpha=0,05)$ dengan menggunakan tabel $2 \times 2$. Perhitungan uji chi square, $\alpha=0,05$ dengan rumus :

$$
X^{2}=\sum \frac{\left(O_{i}-E_{i}\right)}{E_{i}}
$$

Keterangan :

Oi $=$ Frekuensi yang diamati, kategori ke-1

$\mathrm{Ei}=$ Frekuensi yang diharapkan dari kategori ke-1

Dengan interpretasi :

$\mathrm{P}<0,05$ maka $\mathrm{H}_{0}$ ditolak dan $\mathrm{H}_{\mathrm{a}}$ diterima

$\mathrm{P}>0,05$ maka $\mathrm{H}_{0}$ diterima dan $\mathrm{H}_{\mathrm{a}}$ ditolak

Tabel 1.

Hasil Analisis Univariat terhadap Responden di Lokalisasi Kecamatan Margorejo

\begin{tabular}{clcc}
\hline No & \multicolumn{1}{c}{ Variabel } & $\begin{array}{c}\text { Frekuensi } \\
\text { (org) }\end{array}$ & $\begin{array}{c}\text { Persentase } \\
\text { (\%) }\end{array}$ \\
\hline 1. & Umur & & \\
& 24-45 tahun & 39 & $55,7 \%$ \\
& $<23$ tahun dan $>45$ tahun & 31 & $44,3 \%$ \\
2. & Penghasilan & & \\
& $\leq 1.200 .000$ & 22 & $31,4 \%$ \\
& $>1.200 .000$ & 48 & $68,6 \%$ \\
3. & Tingkat Pendidikan & & \\
& $\leq$ SMP & 62 & $88,6 \%$ \\
& $>$ SMP & 8 & $11,4 \%$ \\
$4 . \quad$ Status Pernikahan & & \\
& Belum menikah/Janda & 42 & $60 \%$ \\
& Menikah & 28 & $40 \%$ \\
\hline
\end{tabular}




\section{HASIL DAN PEMBAHASAN}

Berdasarkan kategori umur, sebagian besar responden penelitian berada pada rentang umur 24-45 tahun $(55,7 \%)$. Mayoritas responden memiliki penghasilan $>1.200 .000$ $(68,6 \%)$. Pendidikan sebagian besar responden adalah $\leq$ SMP $(88,6 \%)$. Status pernikahan mayoritas responden adalah belum menikah/ janda (60\%). Pengujian univariat karakteristik responden ditampilkan pada Tabel 1.

Hasil analisis menunjukkan bahwa penggunaan kondom pada PSP untuk variabel umur secara keseluruhan hampir berimbang antara tidak memakai/kadang-kadang dengan yang selalu memakai kondom. Kelompok umur 24-45 tahun yaitu $42,62 \%$ tidak memakai/kadang-kadang dan 57,38\% selalu memakai kondom. Kelompok umur $<23$ tahun dan $>45$ tahun yaitu $66,67 \%$ tidak memakai/kadang-kadang dan 33,33\% selalu memakai kondom.

Mayoritas responden menyatakan tidak pernah/kadang-kadang menggunakan kondom pada variabel penghasilan, baik pada kelompok penghasilan $\leq 1.200 .000 \quad(77,27 \%)$ maupun kelompok penghasilan $>1.200 .000$ $(52,08 \%)$ tidak pernah/kadang-kadang menggunakan kondom.

Terdapat perbedaan penggunaan kondom berdasarkan tingkat pendidikan. Kelompok tingkat pendidikan $\leq$ SMP sebagian besar tidak pernah/kadang-kadang memakai kondom sebanyak 62,90\%, sedangkan kelompok tingkat pendidikan >SMP sebagian besar selalu memakai kondom sebanyak 62,50\%.

Hasil analisis pada variabel status pernikahan menunjukkan bahwa kelompok status pernikahan belum menikah/janda mayoritas tidak pernah/kadang-kadang memakai kondom sebesar $76,19 \%$, sedangkan kelompok status menikah, mayoritas selalu memakai kondom sebesar 64,29\%.

Murtono dkk. (2018) menyatakan bahwa pekerja seks (PSP) mengalami kesulitan dalam melakukan ajakan memakai kondom. Pekerja seks sebenarnya sudah memahami risiko terkena HIV/AIDS maupun IMS, jika tidak memakai kondom secara konsisten. Ketakutan tidak mendapatkan pembayaran transaksi seksual membuat nilai tawar pekerja seks tersebut menjadi lemah. Pelanggan pekerja seks juga belum sepenuhnya memahami arti penting penggunaan kondom karena dalam setiap penyuluhan kesehatan mengenai IMS dan HIV/AIDS lebih mengutamakan sasaran para pekerja seksual.

Pelanggan pekerja seks dengan pendapatan rendah cenderung memilih pekerja seks yang bertarif rendah. Pekerja seksual yang bertarif rendah pada umumnya dapat ditemui di pinggir jalan atau lokalisasi jalanan.

Tabel 2.

Distribusi Penggunaan Kondom pada PSP Berdasarkan Variabel Penelitian di Lokalisasi Kecamatan Margorejo

\begin{tabular}{|c|c|c|c|c|c|c|}
\hline \multirow[t]{2}{*}{ No } & \multirow[t]{2}{*}{ Variabel/Kategori } & \multirow{2}{*}{$\begin{array}{c}\text { Jumlah } \\
\text { Resp } \\
\text { (org) }\end{array}$} & \multicolumn{2}{|c|}{$\begin{array}{l}\text { Tidak pernah/ } \\
\text { kadang-kadang }\end{array}$} & \multicolumn{2}{|c|}{ Selalu } \\
\hline & & & $\mathbf{n}$ & $\%$ & $\mathrm{n}$ & $\%$ \\
\hline \multirow[t]{3}{*}{1.} & Umur & & & & & \\
\hline & $24-45$ tahun & 61 & 26 & 42,62 & 35 & 57,38 \\
\hline & $<23$ tahun dan $>45$ tahun & 9 & 6 & 66,67 & 3 & 33,33 \\
\hline \multirow[t]{3}{*}{2.} & Penghasilan & & & & & \\
\hline & $\leq 1.200 .000$ & 22 & 17 & 77,27 & 5 & 22,73 \\
\hline & $>1.200 .000$ & 48 & 25 & 52,08 & 23 & 47,92 \\
\hline \multirow[t]{3}{*}{3.} & Tingkat Pendidikan & & & & & \\
\hline & $\leq \mathrm{SMP}$ & 62 & 39 & 62,90 & 23 & 37,10 \\
\hline & $>$ SMP & 8 & 3 & 37,50 & 5 & 62,50 \\
\hline \multirow[t]{3}{*}{4} & Status Pernikahan & & & & & \\
\hline & Belum menikah/Janda & 42 & 32 & 76,19 & 10 & 23,81 \\
\hline & Menikah & 18 & 10 & 35,71 & 18 & 64,29 \\
\hline
\end{tabular}


Lokalisasi jalanan meningkatkan risiko penularan HIV karena tidak memperhatikan tingkat kebersihan, keamanan kondom, dan tingkat pemakaian kondom rendah. Lokasi yang cenderung gelap menyebabkan pelanggan maupun pekerja seks tidak dapat memperhatikan cara pemakaian kondom yang baik dan benar, melihat tanggal kadaluarsa dan kualitas kondom, serta cara pelepasan dan pembuangan kondom bekas pakai.

Komisi Penanggulangan AIDS Nasional (KPAN) (2012) melaporkan hanya sekitar $35 \%$ dari pelanggan pekerja seks yang mau memakai kondom, sehingga dapat dikatakan pemakaian kondom di Indonesia tergolong rendah. Rasa tidak nyaman menjadi alasan mengapa mereka enggan memakai kondom tersebut. Pemakaian kondom yang tidak 100\% ini akan dapat mempermudah penularan virus HIV melalui hubungan seksual.

Yanti (2011) menyebutkan bahwa berdasarkan estimasi Depkes dari 190.000270.000 PSP saja sudah tejadi 7-10 juta transaksi seks per tahun, sehingga dapat diperkirakan berapa banyak transaksi seks yang terjadi bila jumlah PSP lebih dari itu. Bisa dibayangkan berapa jumlah transaksi seks yang berisiko menularkan PMS dengan tingkat penggunaan kondom yang rendah (kurang dari 10\%). Kondisi ini membuka kemungkinan terjadinya saling tukar penyakit seksual maupun HIV/AIDS.

KPAN (2010) menyatakan bahwa penggunaan kondom pada hubungan seksual merupakan salah satu strategi pencegahan penularan PMS dan HIV pada kelompok berisiko termasuk kepada PSP dan pelanggannya. Peningkatan kesadaran penggunaan kondom pada pelanggan PSP terbukti dapat menurunkan penularan PMS dan HIV. Blanc \& Wolff dalam Siregar (2018) menyatakan bahwa cakupan penggunaan kondom masih kurang, meskipun sebenarnya pengetahuan perempuan tentang kondom lebih tinggi jika dibandingkan dengan laki-laki. Sikap wanita terhadap kondom lebih positif dan memiliki kesadaran tentang risiko lebih tinggi untuk terinfeksi. Wanita menemui kesulitan untuk menggunakan kondom secara konsisten karena ketidaksetaraan gender dan rendahnya daya tawar wanita.

United Nations Programme on HIV/ AIDS (UNAIDS) (2017) menyebutkan bahwa konsistensi pemakaian kondom adalah seberapa rutin PSP hanya bersedia melayani pelanggan yang menggunakan kondom saat melakukan hubungan seksual. Konsistensi pemakaian kondom mempengaruhi tingkat efektifitas mencegah penularan PMS dan HIV. Kondom dapat mencegah penularan PMS dan HIV jika digunakan secara benar dan efektif. Namun demikian, pemakaian kondom yang tidak konsisten tetap memberikan perlindungan yang lebih jika dibanding dengan tidak pernah menggunakannya sama sekali.

Analisis bivariat menunjukkan bahwa faktor yang berpengaruh terhadap penggunaan kondom pada PSP adalah tingkat penghasilan $(\mathrm{OR}=3,988 ; \mathrm{p}=0,046)$ dan status pernikahan $(\mathrm{OR}=5,76 ; \mathrm{p}=0,001)$. Variabel umur, nilai $\mathrm{p}=0,492$ dengan $\mathrm{OR}=0,712$ menunjukkan tidak terdapat hubungan yang bermakna antara umur dengan konsistensi penggunaan kondom. Kelompok umur 24-45 tahun berpeluang untuk lebih konsisten menggunakan kondom $(57,38 \%)$, sedangkan kelompok umur $<23$ tahun dan $>45$ tahun peluang konsisten menggunakan kondom hanya $(33,33 \%)$. Hasil penelitian Pradipta \& Wuryaningsih (2013) menunjukkan bahwa tidak terdapat hubungan yang bermakna antara umur dengan konsistensi pemakaian kondom. Zarnusi (2002) juga menyatakan bahwa tidak ada hubungan yang bermakna antara umur dengan konsistensi pemakaian kondom.

Tabel 3.

Analisis Bivariat Variabel Bebas terhadap Inkonsistensi Pemakaian Kondom

\begin{tabular}{cccccc}
\hline \multirow{2}{*}{ No } & \multicolumn{1}{c}{ Variabel } & \multirow{2}{*}{ Nilai p } & \multirow{2}{*}{ OR } & \multicolumn{2}{c}{ 95\% CI } \\
\cline { 5 - 6 } & & 0,492 & 0,712 & 0,270 & 1,879 \\
\hline 1. & Umur & 0,046 & 3,988 & 0,994 & 9,840 \\
2. & Tingkat Penghasilan & 0,167 & 2,826 & 0,617 & 12,938 \\
3. & Tingkat Pendidikan & 0,001 & 5,760 & 2,016 & 16,454 \\
4. & Status Pernikahan & 0,001 & &
\end{tabular}


Hasil analisis pada variabel tingkat penghasilan didapatkan nilai $\mathrm{p}=0,046$ dengan $\mathrm{OR}=3,988$ menunjukkan adanya hubungan yang bermakna antara tingkat penghasilan dengan konsistensi penggunaan kondom. Kelompok penghasilan $\leq 1.200 .000$ berpeluang konsisten menggunakan kondom sebesar $22,73 \%$, sedangkan kelompok penghasilan $>1.200 .000$ berpeluang secara konsisten menggunakan kondom sebesar 47,92\%. Karyati (2011) dalam penelitiannya menyatakan bahwa hubungan status pernikahan memiliki hubungan yang lebih kuat dibandingkan tingkat penghasilan terhadap inkonsistensi pemakaian kondom. PSP berpenghasilan kurang yang memiliki konsistensi pemakaian kondom lebih tinggi sebanyak 35 responden (77,8\%). Pekerja seks yang mempunyai penghasilan yang kurang akan berusaha mencari pelanggan sebanyakbanyaknya untuk mencukupi kebutuhannya tanpa memperhatikan keamanan hubungan seks dengan tidak memakai kondom. Khusus untuk PSP berpenghasilan sedang yang memiliki konsistensi pemakaian kondom tinggi sebanyak 7 responden $(53,8 \%)$. PSP berpenghasilan tinggi yang memiliki konsistensi pemakaian kondom yang tinggi sebanyak 9 responden $(50 \%)$. Hasil uji statistik diperoleh nilai $\mathrm{p}=0,057$ sehingga dapat disimpulkan tidak terdapat hubungan yang signifikan antara penghasilan dengan konsistensi pemakaian kondom.

Analisis variabel tingkat pendidikan didapatkan nilai $\mathrm{p}=0,167$ dengan $\mathrm{OR}=2,826$ menunjukkan tidak terdapat hubungan yang bermakna antara tingkat pendidikan dengan konsistensi penggunaan kondom. Kelompok pendidikan $\leq$ SMP berpeluang konsisten menggunakan kondom hanya $37,10 \%$, sedangkan kelompok pendidikan $>$ SMP berpeluang konsisten menggunakan kondom sebesar $62,50 \%$. Hasil penelitian tersebut selaras dengan penelitian Pradipta \& Wuryaningsih (2013) yang menunjukkan bahwa tingkat pendidikan tidak ada hubungan yang bermakna dengan konsistensi pemakaian kondom.

Analisis variabel status pernikahan didapatkan nilai $\mathrm{p}=0,001$ dengan $\mathrm{OR}=5,760$ menunjukkan terdapat hubungan yang bermakna antara status pernikahan dengan konsistensi penggunaan kondom. Persentase responden yang secara konsisten menggunakan kondom pada kelompok menikah adalah 64,29\%, dimana persentase tersebut lebih tinggi dibandingkan dengan kelompok tidak menikah/janda $(23,81 \%)$.

Hasil penelitian tersebut mendukung penelitian sebelumnya yang menyatakan bahwa pernikahan memiliki korelasi positif dengan konsistensi penggunaan kondom pada pekerja seks perempuan. Laki-laki yang belum menikah lebih berpotensi melakukan perilaku seksual berisiko, seperti tidak menggunakan kondom (Yang, et.al., 2010). Penelitian oleh Silawati (2010) membuktikan kecenderungan penggunaan kondom pada Pengguna Narkoba Suntik (Penasun) yang telah menikah. Penasun yang belum menikah memiliki kecenderungan 0,7 kali lebih rendah tidak menggunakan kondom jika dibandingkan dengan Penasun yang sudah menikah (Silawati, 2010).

Pernikahan merupakan salah satu faktor pelindung dari transmisi IMS dan HIV. Daili (2015) menyatakan bahwa status perkawinan berperan dalam membentuk perilaku seksual seseorang. Status perkawinan membantu meningkatkan perilaku seksual yang aman dengan adanya anjuran dari pasangan agar memakai kondom saat berhubungan seks di luar pasangan tetap, terutama bila kedua belah pihak saling terbuka dalam negosiasi seks. Pengaruh tersebut signifikan ditemukan pada laki-laki dibandingkan dengan perempuan. Penelitian oleh Sugiarto (2017) membuktikan bahwa laki-laki yang sudah menikah cenderung memiliki kegiatan seksual yang berbeda dengan laki-laki yang belum menikah. Laki-laki yang sudah menikah lebih memungkinkan untuk berperilaku sehat dan bertangggung jawab dalam aktivitas seksual karena tidak menginginkan adanya dampak negatif dari aktivitas tersebut. Sebaliknya, individu yang belum menikah cenderung melakukan perilaku seksual yang lebih berisiko dengan menggunakan jasa pekerja seks komersial untuk melampiaskan hasrat seksual. 


\section{KESIMPULAN DAN SARAN}

\section{Kesimpulan}

Faktor penentu konsistensi pemakaian kondom pada Pekerja Seks Perempuan (PSP) adalah tingkat penghasilan dan status pernikahan. Pekerja seks perempuan dengan penghasilan yang kurang akan berusaha mencari pelanggan sebanyak-banyaknya untuk mencukupi kebutuhannya tanpa memperhatikan keamanan hubungan seks tanpa memakai kondom. Adapun responden yang memiliki pasangan dalam setiap perilaku atau pengambilan keputusan akan memperhatikan keberadaan pasangannya.

\section{Saran}

Saran penelitian yaitu (1) Dinas Kesehatan Kabupaten Pati perlu mengadakan sosialisasi untuk meningkatkan pengetahuan PSP dan pelanggan tentang penggunaan kondom secara konsisten dan risiko penyakit yang mengikutinya, khususnya di lokalisasi jalanan dimana para PSP mendapatkan penghasilan yang lebih rendah; (2) Dinas Kesehatan Kabupaten Pati perlu mengadakan pelatihan, bimbingan dan pembinaan kepada PSP dalam hal kemampuan menawarkan kondom ke pelanggannya.

\section{DAFTAR PUSTAKA}

Aeni, N. (2015). Faktor Risiko Penularan HIV/AIDS pada Ibu Rumah Tangga di Kabupaten Pati. Laporan Penelitian. Pati: Kantor Penelitian dan Pengembangan Kabupaten Pati.

Aini, S. Q. (2014). Pengambilan Keputusan Sebagai Pekerja Seks Komersial (PSK) pada Remaja Laki-laki (Studi Kasus Terhadap Remaja Laki-laki Pelaku Prostitusi di Kabupaten Pati). Jurnal Litbang: Media Informasi Penelitian, Pengembangan dan IPTEK, X (2), 152160.

Budiono, I. (2012). Konsistensi Penggunaan Kondom oleh Wanita Pekerja Seks dan Pelanggannya. Jurnal Kesehatan Masyarakat, 7 (2), 90-96.
Centers of Disease Control and Prevention. (2014). Gonorrhea-CDC Fact Sheet. https://www.cdc.gov/std/. Diakses tanggal 15 Mei 2015.

Daili. (2015). Infeksi Menular Seksual. Jakarta: Balai Penerbitan FKUI.

Dinas Kesehatan Kabupaten Pati. (2015). Profil Kesehatan Kabupaten Pati Tahun 2015. Pati: DKK Pati.

Fauza, R., Susanti, R., Mardiyaningsih, E. (2014). Faktor-Faktor yang Berhubungan dengan Penggunaan Kondom untuk Pencegahan PMS pada WPS di Lokalisasi Sukosari Bawen Kabupaten Semarang. Prosiding Konferensi Nasional II PPNI Jawa Tengah 2014. Semarang: Universitas Muhammdiyah Semarang 2014

Iskandar, A. (2014). Beberapa Faktor Risiko yang Mempengaruhi Kejadian HIV dan AIDS pada Remaja 14-24 Tahun (Studi Kasus di Kota Pontianak). Tesis. Semarang: Universitas Diponegoro.

Ismiati, Susmini. (2018). Hubungan Penggunaan Kondom dan Status Perkawinan dengan Kejadian Infeksi Menular Seksual pada Wanita Usia Produktif. Jurnal Ilmiah Bidan, III (2), 17-20.

Karyati, S. (2011). Faktor-Faktor yang Mempengaruhi Konsistensi Wanita Penjaja Seks dalam Pemakaian Kondom untuk Mencegah Penularan PMS dan $H I V$ di Pati. Tesis. Depok: Universitas Indonesia.

Kementerian Kesehatan Republik Indonesia. (2011). Pedoman Nasional Penanganan Infeksi Menular Seksual 2011. Jakarta: Kemenkes RI.

Kementerian Kesehatan Republik Indonesia. (2014). Estimasi dan Proyeksi HIV/AIDS di Indonesia Tahun 2011-2016. Jakarta: Kemenkes RI.

Kementerian Kesehatan Republik Indonesia. (2017). Laporan HIV/AIDS Triwulan I (Januari-Maret) Tahun 2017. Jakarta: Kemenkes RI. 
Komisi Penanggulangan AIDS Kabupaten Pati. (2014). Analisa Situasi HIV dan AIDS di Kabupaten Pati 2014. Pati.

Komisi Penanggulangan AIDS Nasional. (2010). Strategi dan Rencana Aksi Nasional Penanggulangan HIV/AIDS Tahun 2010-2014. http:// www.aidsindonesia.or.id. Diakses tanggal 13 Mei 2011.

Komisi Penanggulangan AIDS Nasional. (2012). Analisa Situasi HIV dan AIDS di Indonesia. http://www.aids-ina.org. Diakses tanggal 6 Maret 2015.

Kurnia, D. (2013). Buku Ajar Kesehatan Reproduksi dan Keluarga Berencana untuk Mahasiswa Bidan. Jakarta: Trans Info Media.

Lembaga Swadaya Masyarakat Fatayat NU SSR II Kabupaten Pati. (2018). Daftar Tempat Hiburan Karaoke/Cafe di Kabupaten Pati. Pati: LSM Fatayat NU SSR II Kabupaten Pati.

Lokollo, F. Y. (2009). Studi Kasus Perilaku Wanita Pekerja Seksual Tidak Langsung dalam Pencegahan IMS, HIV dan AIDS di Pub \& Karaoke, Cafe, dan Diskotek di Kota Semarang. Tesis. Semarang: Universitas Diponegoro.

Marlina, Suryanto, Masadi, N. (2010). Perilaku Pekerja Seks Komersial dalam Penggunaan Kondom untuk Pencegahan Transmisi HIV/AIDS di Lokalisasi Teleju Kota Pekanbaru. Jurnal Kesehatan Komunitas, 1 (1), 21-31.

Marmi. (2013). Kesehatan Reproduksi. Yoyakarta: Pustaka Pelajar.

Murtono, D. (2016). Beberapa Faktor yang Berpengaruh terhadap Kejadian HIV/ AIDS pada Populasi Kunci di Kabupaten Pati. Tesis. Semarang: Universitas Diponegoro

Murtono, D., Riyanto, P., Shaluhiyah, Z. (2018). Influential Host Factors to The Incidence of HIV/AIDS in Key Populations in Pati District. Kesmas: National Public Health Journal, 13 (1), 17-22.
Musyarofah, S. (2014). Beberapa Faktor yang Berhubungan dengan Kejadian HIVI AIDS pada Wanita (Studi Kasus di Kabupaten Kendal). Tesis. Semarang: Universitas Diponegoro.

Ninik, Nugraha, P., Riyanti, E. (2012). Perilaku Wanita Pekerja Seks dalam Pencegahan Infeksi Menular Seksual (Studi Kualitatif pada Anak Asuh di Lokalisasi Gembol, Sukosari, Bawen, Kabupaten Semarang). Media Kesehatan Masyarakat Indonesia, 11, 71-74.

Peraturan Menteri Kesehatan Republik Indonesia Nomor 21 Tahun 2013 tentang Penanggulangan HIV dan AIDS.

Peraturan Menteri Kesehatan Republik Indonesia Nomor 74 Tahun 2014 tentang Pedoman Pelaksanaan Konseling dan Tes HIV.

Pradipta, M. N., Wuryaningsih, C. E. (2013). Faktor-Faktor yang Mempengaruhi Konsistensi Pemakaian Kondom pada Waria Binaan Puskesmas Bogor Timur dalam Upaya Pencegahan HIV/AIDS Tahun 2012. Skripsi. Jakarta: FKM UI. http://lib.ui.ac.id/naskahringkas/2015-09/ S45498-Marlya\%20Niken\%20Pradipta. Diakses tanggal 11 Januari 2019.

Rustam, S. W. (2016). Gambaran Tingkat Pengetahuan Pasangan Usia Subur tentang Alat Kontrasepsi Kondom sebagai Salah Satu Pencegahan HIV/AIDS di Lingkungan Buttadidia Kelurahan Mawang Tahun 2016. Karya Tulis Ilmiah. Makassar: Universitas Islam Negeri Alauddin Makassar.

Sembiring, E., Sembiring, R. (2013). Pengaruh Predisposing Faktor, Enabling Faktor dan Reinforcing Faktor terhadap Upaya Pencegahan Infeksi Menular Seksual pada Wanita Pekerja Seks Komersial di Lokalisasi Warung Bebek Serdang Bedagai. Seminar Nasional Membangun Budaya Akademik Melalui Kompetitif Penelitian Universitas Al Azhar Medan. 27 November: 1-17. 
Silawati, V. (2010). Faktor-Faktor yang Berhubungan dengan Penggunaan Komdom pada Gay di Jakarta Tahun 2010. Tesis. Depok: Universitas Indonesia.

Sofia, L. (2010). Hubungan antara Pengetahuan tentang Gonorrhea dengan Kepatuhan Pemakaian Kondom (Studi Pada Wanita Pekerja Seksual) di Lokalisasi Sunan Kuning Semarang. Skripsi. Semarang: Universitas Diponegoro.

Siregar, R. N. (2018). Faktor-Faktor yang Berhubungan dengan Penggunaan Kondom pada Pelanggan WPS sebagai Upaya Pencegahan HIV/AIDS di Desa Marindal I (Satu) Tahun 2017. Wahana Inovasi, 7 (2), 103-112.

Sugiarto. (2017). Hubungan Status Pernikahan dan Kepemilikan Kondom dengan Penggunaan Kondom Saat Melakukan Hubungan Seksual pada Pasangan Tidak Tetap Pengguna Napza Suntik. Jurnal Kesehatan Terpadu, 1 (2), 44-48.

Sumiyati, Hadi, M. Y. (2013). Faktor-Faktor yang Mempengaruhi Penggunaan Alat Kontrasepsi Kondom. Jurnal Kesehatan Metro Sai Wawai, 6 (1), 8-15.

Susanti, R., Nirmasari, C. (2015). FaktorFaktor yang Berhubungan dengan Penggunaan Kondom untuk Pencegahan PMS pada WPS di Lokalisasi Kabupaten Semarang. Jurnal Keperawatan Maternitas, 3 (2), 82-89.

United Nations Children's Fund (UNICEF). (2004). HIV-AIDSbooklet part3. Jakarta: UNICEF

United Nations Programme on HIV/AIDS (UNAIDS). (2017). UNAIDS Data 2017. Geneva: UNAIDS
Wirastri, D., Deliana, Sri M., Mukarromah, S. B. (2017). Korelasi Pengetahuan, Kepuasan, Motivasi dengan Konsistensi Pemakaian Kondom pada Pelanggan WPS di Sunan Kuning. Unnes Journal of Public Health, 6 (3), 161-166.

Yang, C., Latkin, C., Luan R., Nelson, K. (2010). Condom Use with Female Sex Workers among Male Clients in Sichuan Province, China: The Role of Interpersonal and Venue-Level Factors. Journal of Urban Health: Buletin of the New York Academy of Medicine, 87 (2), 292302

Yanti. (2011). Buku Ajar Kesehatan Reproduksi. Jakarta: Pustaka Rihana.

Zarnusi. (2002). Faktor-Faktor yang Berhubungan dengan Konsistensi Pemakaian Kondom pada Waria Pekerja Seks di Wilayah Jakarta Tahun 2000. Skripsi. Depok: Universitas Indonesia.

\section{BIODATA PENULIS}

Dwi Murtono, lahir di Grobogan pada tanggal 11 Desember 1985. Pendidikan Sarjana Kesehatan Masyarakat di Universitas Muhammadiyah Surakarta dan Magister Epidemiologi di Universitas Diponegoro Semarang. Saat ini bekerja sebagai Epidemiolog Kesehatan Ahli Pertama di Rumah Sakit Umum Daerah Kayen Kabupaten Pati. 